豚肉のカルシウム含量ならびに测定年度, 季節, 品種, 筋肉および性による差異*

\author{
玉手六朗・大高文男
}

获城大学呚学部，茨城県阿見町 300-03

(1978. 8. 15 受付)

\begin{abstract}
要 約 豚肉の常在的な無譏成分のうたカルシウム（Câ)についてその含量を明らかにし，また 2, 3 の要因一一測定年度 $(1965,1966$ および 1968 年)，季節（春放よび秋），品種（ランドレース種およ

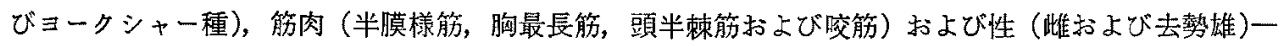
による差異を検討した，すなるち，履歴が明らかで，飼育条件怙よび屠殺方法などが規定されている 65 頭のブタから筋肉試料を採取し，ポーラログラフ法によりその Ca 合量を測定して，つぎの結果を得 た. 豚肉の $\mathrm{Ca}$ 含量を，新鮮物中および兏分中の值で各要因別に示した（表 1). そのうち全試料 (219 個）についての平均值 (95\%信頼限界) おょよび变動係数は, 新鮮物 $100 \mathrm{~g}$ 中で $6.0 \pm 0.3 \mathrm{mg}$ および $31.7 \%$ ，灰分 $1 \mathrm{~g}$ 中で $5.5 \pm 0.2 \mathrm{mg}$ および $33.5 \%$ あった. また 2,3 の要因による豚肉の Ca 舍量 の差異は, 主勃果では筋肉要因の場合が最大で, 品種要因がこれにつぎ, 季節要因もかなり大きかった が，年度要因および性要因の影響は全く認められ交かった，交互作用では，年度×品種が有意の大きな 影響を，また季節×品種および季節×筋肉が有意の影響をそれぞれ示した。
\end{abstract}

日畜会報，50(4)：229-234，1979

䀠肉の無機成分含量およびその分布を基礎的に検討卞 るため，著者らはさきに発光分光分析法により豚肉の髙 機成分の分有ならびに常在性について報告した"1). その 結果確認された常在的な無機成分のうち,ナトリウム $(\mathrm{Na})$ ，カリウム $(\mathrm{K})$ ，マンガン $(\mathrm{Mn})$ ，イオウ $(\mathrm{S})$ およ びマグネシウム $(\mathrm{Mg})$ について順次これらの豚肉中の 合量を測定し，をた，2，3の要因による差異を明らかに してきだ-5).

本報では，豚肉の常在的な無機成分であるカルシウ ム (Ca) について, 履歴が明らかな豚肉試料老用いて その含量を测定し，さらに測定年度，季節，品種，筋 肉就び性要因による差異を明らかにしたので報告す る.

\section{方法}

1. 実験材料: 1965 1968 年の間に, 茨城県養豚試験 場において，豚産肉能力検定に用いられたランドレース 種 33 頭およびョークシャー種 32 頭, 計 65 頍の春子お よび秋子を供試した。すなわち，屠殺後，半丸のまま約 $4^{\circ} \mathrm{C}$ の泠蔵庫中にて約 24 時間経過した 65 頭のプタの枝

* 豚肉の無機成分に関する研究 $\mathrm{X}$
肉より, 3 部位の筋肉 [半膜様筋, 背最長筋: 第 6 胸推 部（最近，胸最長笳と称するので，以下同名称を用い る）拉よび頭半棘筋】を，また，このうち 24 頭からは 咬筋む探取した。これらの筋肉より脂肪および結合組織 そできるだけ除き，細切闪としたものを試料とした，試 料数は全部で 219 個である. なお供詿豚の履歷, 飼料, 飼養条件，豚産肉能力検定の方法成繥などは，それぞれ 関係資料に記載されているとおりである6-8).

2. 実験方法：試料肉約 $20 \mathrm{~g}$ 落磁製ルツボに精称し, 予備灰化したのち，電気师にて 500 550 Cで約 16 時間 灰化した，この兏を少量の水で湿してから $\mathrm{HCl}$ (1:1) に溶かし，いった九蒸発乾固したのち， $0.2 \mathrm{~N} \mathrm{HCl} \mathrm{で} 50$ $\mathrm{m} l$ 定容とした。 この際長沢 ${ }^{9}$ および久保 ${ }^{10)}$ の報告を参考 として Ca の混入または損失のないように留意した。つ きにこの $0.2 \mathrm{~N} \mathrm{HCl}$ 溶液試料として, 著者占が改良し たポーラログラフ法"11により Ca を測定した。用いた装 置は，柳本 PS-52 型交直両用ポーラログラフで， $25 \pm$ $0.5^{\circ} \mathrm{C}$ の恒温槽中で水銀池它対極として分析を行なった. は技滴下水銀電極の特性は, $\mathrm{m}=2.46 \mathrm{mg} / \mathrm{sec} ., \mathrm{t}=3.33$ sec./drop であった．水はイオン交捘したすのをさらに 硬質ガラス製容器で再蒸留したもの学用い，また試薬類 はすべて特級品を用いた。 
結果

1. 豚肉 $\sigma \mathrm{Ca}$ 含

豚肉 219 䳝料について $\mathrm{Ca}$ 含最老澌定した結果を各要 因別に示すと，表 1 のとおりである。

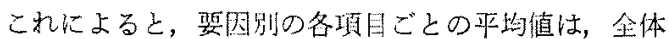
のそれに比べて秋子，ヨークシャ一㮒および咬筋の塄合

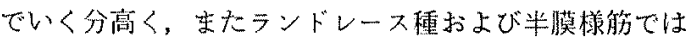
いく分低く，そして 1968 年および春子の埸合はかなり 低いこと怔示された。この稀の要国別の各項目のそれ では，あまり差が諗められなかった。同栐に変動係数に ついてみると，全体のそれに比べて，1965 年，ランドレ

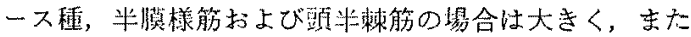
1966 年, ヨークシャー種, 胸最長筋および咬筋でいく分 小さく、そして 1968 年ではかなり小さかったが，このほ かの要因別各項目ではあまり差のないことが示された。

2. 各要国による $\mathrm{Ca}$ 舍量の差異

年度，季節，品種，筋闪および性の5 要因による胆测
の $\mathrm{Ca}$ 拿量の留動を分析した．灰分 $1 \mathrm{~g}$ 中の值を用いて 分教分析を行なった結果は，表 2〜5 に示すと拈りであ 亏.

咬肪を除く半膜様筇，胸最長筋および頭半棘筋の Ca 含量について，対応のあるデータ183 個(1966 年度の昗 筇 20 個乱よび 1968 年度の4筇肉 16 個，合計 36 個定全 体の219 個から差引いたもの）を用いて，5元配固で分 政分析を行なった結果(表 2)，主効果としては，季節，品 種および筋肉間に有意の差が認められたが，年度および 性の間には住意の差方認められなかった，交互作用につ

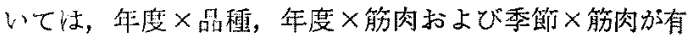
意の然を示したが，そのほかの場合はいずれも有意でな かった，末た等与落についてみると，笳肉および年度 品種要因が最も大きく，これについで季節，品䅜および 季節×筇肉要因でいく分大であったが，年度×筋肉要因 では小さかった．1965 年の分析結果から，Ca含量は筋 肉間で異なることがわかったので，1966 年度より咬筋 安追加して分析に供した，そこで咬筋学含む対応のある

Table 1. Calcium content in pork from 65 pigs.

\begin{tabular}{|c|c|c|c|c|c|c|c|c|c|}
\hline \multirow{2}{*}{ Factor } & & \multicolumn{4}{|c|}{ Wet basis ${ }^{2}$} & \multicolumn{4}{|c|}{ Ash basis ${ }^{81}$} \\
\hline & & Range & $S^{41}$ & $\mathrm{X}^{5 !}$ & Mean & Range & $\mathrm{S}$ & $\mathrm{X}$ & Mean \\
\hline \multicolumn{10}{|l|}{ Year } \\
\hline 1965 & $(111)^{7)}$ & $2.4-9.8$ & 2.1 & 35.1 & $6.0 \pm 0.4$ & $2.0-9.8$ & 2.0 & 36.9 & $5.5 \pm 0.4$ \\
\hline 1966 & $(92)$ & $3.2-9.8$ & 1.6 & 26.0 & $6.3 \pm 0.3$ & $2.9-8.9$ & 1.6 & 27.1 & $5.8 \pm 0.3$ \\
\hline 1968 & (16) & $3.1-6.1$ & 0.8 & 18.3 & $4.4 \pm 0.4$ & $2.7-5.3$ & 0.7 & 17.9 & $3.8 \pm 0.4$ \\
\hline \multicolumn{10}{|l|}{ Season } \\
\hline Spring & (98) & $2.4-9.5$ & 1.5 & 30.1 & $4.9 \pm 0.3$ & $2.0-8.5$ & 1.4 & 31.1 & $4.5 \pm 0.3$ \\
\hline Autumn & $(121)$ & $2.8-9.8$ & 1.8 & 25.7 & $6.9 \pm 0.3$ & $2.5-9.8$ & 1.7 & 27.4 & $6.3 \pm 0.3$ \\
\hline \multicolumn{10}{|c|}{ Breed } \\
\hline Landrace & $(111)$ & $2.4-9.8$ & 1.8 & 33.9 & $5.4 \pm 0.3$ & $2.0-8.9$ & 1.7 & 35.7 & $4.8 \pm 0.3$ \\
\hline Yorkshir & $e(108)$ & $3.2-9.8$ & 1.8 & 26.3 & $6.7 \pm 0.3$ & $2.8-9.8$ & 1.7 & 27.4 & $6.2 \pm 0.3$ \\
\hline \multicolumn{10}{|l|}{ Muscle ${ }^{\prime \prime}$} \\
\hline$-\mathrm{H}$ & $(65)$ & $2.4-9.6$ & 2.0 & 38.7 & $5.2 \pm 0.5$ & $2.0-8.5$ & 1.8 & 39.4 & $4.6 \pm 0.4$ \\
\hline$-\mathrm{L}$ & $(65)$ & $4.1-9.5$ & 1.4 & 22.0 & $6.5 \pm 0.4$ & $3.3-8.9$ & 1.3 & 22.7 & $5.8 \pm 0.3$ \\
\hline$-\mathrm{S}$ & $(65)$ & $3.1-9.8$ & 2.0 & 33.1 & $6.1 \pm 0.5$ & $2.6-9.8$ & 2.0 & 35.3 & $5.8 \pm 0.5$ \\
\hline$-\mathrm{M}$ & (24) & $4.1-9.8$ & 1.8 & 26.3 & $6.8 \pm 0.8$ & $3.6-8.9$ & 1.7 & 26.6 & $6.4 \pm 0.7$ \\
\hline \multicolumn{10}{|l|}{ Sex } \\
\hline Sow & (115) & $2.8-9.8$ & 2.0 & 31.9 & $6.1 \pm 0.4$ & $2.5-9.8$ & 1.9 & 34.0 & $5.6 \pm 0.4$ \\
\hline Barrow & $(104)$ & $2.4-9.8$ & 1.9 & 31.5 & $5.9 \pm 0.4$ & $2.0-9.4$ & 1.8 & 32.8 & $5.4 \pm 0.3$ \\
\hline Total & $(219)$ & $2.4-9.8$ & 1.9 & 31.7 & $6.0 \pm 0.3$ & $2.0-9.8$ & 1.8 & 33.5 & $5.5 \pm 0.2$ \\
\hline
\end{tabular}

1) Muscle-H: M. Semimembranosus, - L: M. Longissimus thoracis, $-\mathrm{S}$ : M. Semispinalis capitis, -M. M: Masseter. 2) $\mathrm{mg} / 100 \mathrm{~g}$ of muscle. 3) $\mathrm{mg} / 1 \mathrm{~g}$ of ash. 4) Standard deviation. 5) Coefficient of variation (\%). 6) $95 \%$ confidence limit. 7 ) Number of samples. 
Table 2. Analysis of variance of calcium content ${ }^{11}$ in pork (Part I).

\begin{tabular}{|c|c|c|}
\hline Factor & $\begin{array}{l}\text { Variance } \\
\text { ratio }\end{array}$ & $\begin{array}{c}\text { Contribution } \\
\text { rate }(\%)\end{array}$ \\
\hline A $(\text { Year })^{2)}$ & 3.19 & 1.3 \\
\hline B (Season) & $11.96^{* *}$ & 6.8 \\
\hline C (Breed) & $13.28^{* *}$ & 7.6 \\
\hline D (Muscle) $)^{s}$ & $17.44 * *$ & 20.3 \\
\hline $\mathrm{E}(\operatorname{Sex})$ & 0.14 & 0.0 \\
\hline$A \times B$ & 0.09 & 0.0 \\
\hline $\mathrm{A} \times \mathrm{C}$ & $34.09 * *$ & 20.4 \\
\hline$A \times D$ & $3.40^{*}$ & 3.0 \\
\hline$A \times E$ & 0.23 & 0.0 \\
\hline $\mathrm{B} \times \mathrm{C}$ & 6.39 & 3.3 \\
\hline $\mathrm{B} \times \mathrm{D}$ & $8.67 * *$ & 9.4 \\
\hline $\mathrm{B} \times \mathrm{E}$ & 0.35 & 0.0 \\
\hline$C \times D$ & 1.99 & 1.2 \\
\hline $\mathrm{C} \times \mathrm{E}$ & 0.07 & 0.0 \\
\hline $\mathrm{D} \times \mathrm{E}$ & 1.27 & 0.3 \\
\hline Error & - & 26.4 \\
\hline
\end{tabular}

1) Ash basis, 183 samples, 61 heads. 2) 1965 \& 1966. 3) Muscle -H, L, S. * $\mathrm{P}<0.05$ ** $\mathrm{P}<0.01$.

Table 3. Analysis of variance of calcium

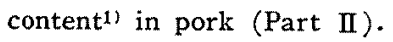

\begin{tabular}{lrc}
\hline \hline Factor & Data & $\begin{array}{c}\text { Variance } \\
\text { ratio }\end{array}$ \\
\hline Breed & III + IV & 1.43 \\
Muscle $^{2)}$ & I & $7.78^{*}$ \\
& II & 1.02 \\
& III & $21.60^{* *}$ \\
Sex & IV & $29.14^{* *}$ \\
& III & 3.10 \\
& IV & 4.51
\end{tabular}

1) Ash basis (mg/1 g of ash). 2) Muscle-H, L, S, M. 3) I: 1966, Spring, Yorkshire, 4 heads. II: 1968, Spring, Landrace, 4 heads. III: 1966, Autumn, Landrace, 8 heads. IV: 1966, Autumn, Yorkshire, 8 heads. $* \mathrm{P}<0.05$ $* * \mathrm{P}<0.01$.

データについて分散分析を行なった結果（表 3)，品種お よび性の間に有意差は認められず，筋肉間では 4 例中 3 例に有意差のあることがわかった，以上のように筋肉間 に有意差のあることが示されたので，どの筋肉間に㾏が あるか子梌定した、その結果(表 4), 半膜様筋と胸最唇笳
Table 4. Differences in calcium content"1 of pork among muscles ${ }^{2}$.

\begin{tabular}{cllllll}
\hline \hline \multirow{2}{*}{ Data $^{31}$} & \multicolumn{7}{c}{ Muscle $^{21}$} \\
\cline { 2 - 7 } & H/L & H/S & L/S & H/M & L/M & S/M \\
\hline I & $2.3^{* *}$ & $1.6^{*}$ & 0.9 & $1.9^{* *}$ & 0.6 & 0.3 \\
II & 0.8 & 0.5 & 0.3 & 0.3 & 0.5 & 0.2 \\
III & 0.3 & $2.9^{* *}$ & $2.6^{* *}$ & $2.1^{* *}$ & $1.8^{* * *}$ & 0.8 \\
IV & 0.4 & $2.7^{* *}$ & $2.3^{* *}$ & $3.1^{* *}$ & $2.7^{* * *}$ & 0.4 \\
V & $4.0^{* *}$ & $0.9^{*}$ & $2.1^{* *}$ & - & - & - \\
VI & 1.5 & 0.7 & 0.8 & - & - & - \\
VII & 2.7 & 1.3 & 1.4 & - & - & - \\
VII & 1.0 & 0.4 & 1.4 & - & - & - \\
IX & 0.2 & 0.2 & 0.0 & - & - & - \\
\hline
\end{tabular}

1) Ash basis (mg/1 g of ash). 2) See footnote in Table 1. 3) I-IV: See footnote in Table 3. V: 1965, Spring, Landrace, 3 muscles (H, L, S), 14 heads. VI: 1965, Autumn, Landrace, 3 muscles (H, L, S), 3 heads. VII: 1966, Spring, Landrace, 3 muscles (H, L, S), 4 heads. VIII: 1965, Spring, Yorkshire, 3 muscles (H, L, S), 4 heads. IX: 1965, Autumn, Yorkshire, 3 muscles $(\mathrm{H}, \mathrm{L}, \mathrm{S}), 16$ heads. $* \mathrm{P}<0.05 \quad * * \mathrm{P}<0.01$.

Table 5. Analysis of variance of calcium content') in pork (Part III).

\begin{tabular}{cccc}
\hline \multirow{2}{*}{ Factor } & \multicolumn{3}{c}{ Variance ratio } \\
\cline { 2 - 5 } & $\begin{array}{c}\text { Muscle } \\
-\mathrm{H}^{2}\end{array}$ & $\begin{array}{c}\text { Muscle } \\
-\mathrm{L}^{3)}\end{array}$ & $\begin{array}{c}\text { Muscle } \\
-\mathrm{S}^{4)}\end{array}$ \\
\hline 1965 vs. 1968 & 0.95 & $8.39 *$ & 0.06 \\
1966 vs. 1968 & 0.48 & $10.06 *$ & 1.64 \\
\hline
\end{tabular}

1) Ash basis (mg/1 g of ash). 2)-4) See foot. note in Table 1. * $\mathrm{P}<0.05$ Data: 1965; Spring, Landrace, 3 muscles (H, L, S), 14 heads; 1966, Spring, Landrace, 3 muscles (H, L, S), 4 heads; 1968, Spring, Landrace, 3 muscles $(H, \mathrm{~L}, \mathrm{~S}), 4$. heads.

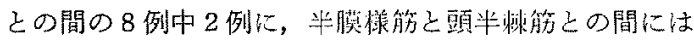
8 例中 4 例に，胸最長筋之頙半料䈤の間の 8 例中 3 例に， 半膜橔笳已咬筋の間の 4 例中 3 例に，そ乙て胸最長筋乙

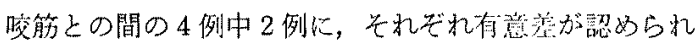
た. なお䫑半梀筋と咬筋との間の4例については，全く 何意差が認められなかった。㭬肉のCa含㫿は，1965年 と1966年との間に墲が認められなかったが、さらに1968 年のデータを追加して年度間の差を检討した結果（丧 5), 胸最長笳について 1965 年と 1968 年および 1966 年 と 1968 年との間に有意屠のあることが㤎められた。 


\section{考察}

食肉の $\mathrm{Ca}$ 含量に関す吕報告は外国においてはかなり 多いが，牛肉についてのものが中心で，豚肉については 少ない，一方わが国では，豚肉はもとより，他の食肉に 関しても $\mathrm{Ca}$ 含量の報告は極めて少ない，豚肉の $\mathrm{Ca}$ 含 量についてのこれら文献値 ${ }^{12-19}$ を，本報の著者らの測定 值と比較して示すと，表6のとおりである.

これらの文献值は，供試家音の履歴，飼育条件，屠殺 方法，品種，測定年度および筋肉名などの不明なものが 多い，一心便宜的に著者らの測定結果と比べてみると， 斉滕・小島 ${ }^{12}$, LEVERTON and ODELI ${ }^{14)}$, INKLAAR and SANDIFORT ${ }^{19)}$ のそれぞれの報告には, 著者らの測定值よ り高い值が示されている. しかし斉藤・小島の場合，バ ークシャー豚肉では極めて高いものの，ヨークシャー豚 肉では低く、著者らの值と大差がない、したがって品種 による差かむしれないが，著者らはバークシャ一豚肉に ついては分析していないので，この点は不明である。

LEVERTON and ODELL14)の場合は, 試料乙して loin chop を用いているとさはすかっている分，分析法や品種は示 されておらずまた INKLAAR and SANDIFORT ${ }^{19)}$ の場合 は，キレート滴定法によっているので分析法のちがいに よるものかもしれないが，それにしては差がありすぎる し，その上品種や筋肉名については不詳であり，いずれ の埸合む高測定値が得られた理由は明らかでないなな
そのほかの文献值は，著者らの值とほとえど差がないよ うであった。

本報の結果より，豚肉の $\mathrm{Ca}$ 含量は季節，品種和よび䈃 肉によりかなり，また測定年度によりわずが影樂され ることを前記した。すなわち，䀠肉の Ca 合量は，春子よ り秋子の方が，またランドレース粳よりヨークシャー稞

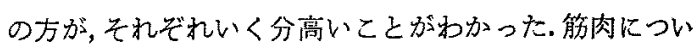
ては，胸最長筋，頭半刺筋および咬筋の3 筋肉ではほほ 同程度の $\mathrm{Ca}$ 合量で, 半膜様筋のみがこれら 3 筋肉より いく分低い值を示した。なお 1968 年のCa 合量は, 1965 年または 1966 年に比べていく分低い上うであった.

以上のことから，豚肉中の Ca 含量定示寸には，供試 豚の履歷，飼育条件，屠殺方法などの明らかなブタ学用 い，少なく之も季節，品種㘧よび筋肉名定示ことが必 要と考えられる. な打測定年度そのほ加の供試肉の履歴 も示すべきであるう.

飼料中のミネラルの肉への移行については, 斉藤・小 島12分飼料中のカリ，石灰およびリン酸が豚肉に移行し たことを竍告しているが，この閒題はなお今後研究する

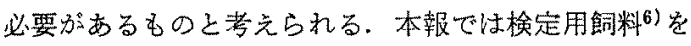
給与しているので，飼料の影響は同一とみなしている が，参考乙して一応検定用飼料中の $\mathrm{Ca}$ 含量安測定した とこる, No. 1 飼料（予储飼育期間杼よび検定前期用） で $9.0 \mathrm{mg} \%$ ，また No. 2 飼料 (検定後期用) で $11.6 \mathrm{mg}$ \%であった.

Table 6. Comparison of author's and published data for calcium content in pork.

\begin{tabular}{|c|c|c|}
\hline Reporter & Content* & Remarks \\
\hline SaIto M. \& M. KoJima (1935) ${ }^{12)}$ & 19.2 & Berkshire \\
\hline$(\prime \prime)$ & 5.3 & Yorkshire \\
\hline Winton A.L. \& K.B. Winton $(1937)^{181}$ & 7.8 & - \\
\hline LEVERTON R.M. \& G.V. Odeli $(1958)^{14)}$ & 14 & Loin chop \\
\hline McC ANCE R.A. \& E.M. WIdDowson $(1960)^{15 !}$ & 4.3 & - \\
\hline Price J.F. \& B.S. SchWeigerT $(1960)^{16}$ & 9 & — \\
\hline IIdA M. \& H. NAKASE $(1962)^{17)}$ & 10 & Lean \\
\hline KAGAKUGIJUTSUCHO $(1964)^{18)}$ & 4 & Ham \\
\hline$(11)$ & 9 & Shoulder \\
\hline$(\prime \prime)$ & 9 & Belly \\
\hline$(\prime \prime)$ & 7 & Loin \\
\hline INKLAAR P. \& J. SANDIFORT $(1967)^{19)}$ & $\begin{array}{l}16-23 \\
\mathrm{Av} .=18\end{array}$ & - \\
\hline $\begin{array}{l}\text { Tamate R. \& F. OHTAKA (1973) } \\
\text { (Authors) }\end{array}$ & $\begin{array}{l}2.4-9.3 \\
\mathrm{Av}=6.0 \\
\mathrm{X}=31.7 \%\end{array}$ & Lean \\
\hline
\end{tabular}

* Wet basis (mg/100 g of muscle) Av. \& X: See footnote in Table 1. 


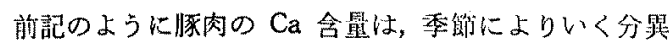
なることが示された。こ机は季節によりブタの成辰速度 に差が生じたことが一因ではないかと考えられる。和島 ・潼㺩 ${ }^{20}$ は,ブタの屠殺洔期之肉質審监得点との闌に相 関のあることを報告しており，著者ら ${ }^{21}$ 屯季節によって 顺肉の脂肪およびタンパク質含量に疘のあることを報告 した. 一般にブタの成長速度は寒い冬を経てゅく秋子の ほう加，暑い夏を経過する春子より劣るといわれてい る. また豚肉の Ca 合量は品䅜によってもいく分異なっ たが、これは品種によってブタの成長速度が巽なること 上閣連があるのではないかと推定される．90 kg 到達日 龄または成長速度をみると，ヨータシャ一種はランドレ 一ス種またはハンブシャー種より一般に少ることが知ら れている7.22,23)．このように豚肉の $\mathrm{Ca}$ 含量が李節およ び品㯖で異なるのは，ブタの成長速度の㾏によるのでは ないる推定されたので，本報で供試したブタについて 成長速度におよぼす各要因の影留家剱討した。すお ら，成辰速度（一日当り平均增体垔）に执よばす季節お よび品種の影響について解析した結果，さきに示したよ

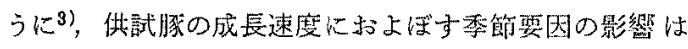
かなり大きく（奇与率 $17.5 \%$ )，また品種要因は非常に

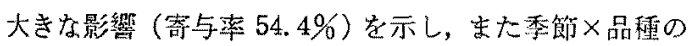
交互作用にもいく分影響が認められた. このようにブタ の成長速度ならびに豚肉の $\mathrm{Ca}$ 而量におよぼす季節およ び品種要因の影響を対比してみると，影䁹の程度は別々 してその傾向は一致していることがホされた。すなか ち，季節姴因については $\mathrm{Mn}^{3)} ， \mathrm{~S}^{4}$ お゙よび $\mathrm{Mg}^{5}$ 含量の 場合と同椩に，また品種要因については $\mathrm{Na}^{21}, \mathrm{~K}^{2}$ 和よ び $\mathrm{Mn}^{3}$ 含量の場合と同棁に，豚肉の Ca 拿量の場合も ブタの成長速度と関連して影篦を受けていることが認め られた.

豚肉の $\mathrm{Ca}$ 含量は笳肉によってかなり暴なり，ての影 響の程度は寄与率として 20.4\%で，主効果のうちでは 最も大きかった。しかし，笳肉要国の影悡は，さきに報 告した $\mathrm{Na}^{2}$ ， $\mathrm{K}^{2}$ 抽び $\left.\mathrm{Mg}^{5}\right)$ 含量の場合よりその程度

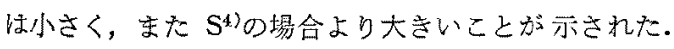

そして $\mathrm{Ca}$ 含量が, 半膜様筋と胸最長筋, および頭半棘 筋と晈筋の 2 群にほぼ大別され，雨群間の Ca 含量に差

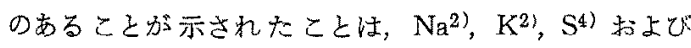
$\mathrm{Mg}^{5}$ 合量の場合の傾向と一致した。これらのことから Ca 含量功異なり，また一般組成に差があるのは，これ ら両群の筋肉の生理的な機能が相虺していること ${ }^{21.24)}$ に その一因があるのではないかと推定される。なお年度要 因による Ca 含量の差巽は，胸最長筋の1965 年と 1968 年および 1966 年と 1968 年との間にのみ諗められた
が，全体としては年度による受はほとえどないるのと考 えられた。杰た性要因については， $\mathrm{Na}^{2} ， \mathrm{Mn}^{3}$ 沶よび S4) 含致の昜含と同様に全く認められなかった。なお前

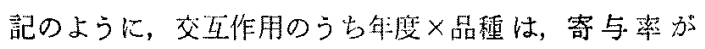
$20.4 \%$ と主效果の筋闪要国に匹敵する大きな影響定示し た。これは年度要因が主效身として有意の影照定され かったものの，年度と品種の組合せによっては大きな影

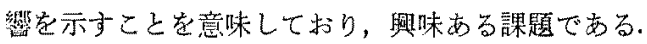

本研究を实施するに際し，鹉料の採取にご協力頂いた

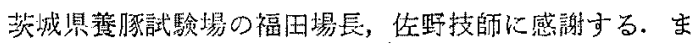
たデータの統計妈理に当り，ご助言を頂いた本学部の田 中助教授拈よび谷口助教授に的意を表する。な本研觉 の一部は，日本音鷹学会第 53 回および55 回大会（1967 および1969有）において発表した。

\section{文献}

1）互手六胡・大高文男，日音会報，43：251-256. 1972.

2）互手六朗・大高文男，日畜会報，44：306-314. 1973.

3) 玉手六朗 - 大高文男, 茨大表学術㪕告, 第 22 号: 81-86. 1974.

4) 玉手六朗 - 大高文男, 奖大祡学術報告, 第 23 号: 29-34. 1975.

5）王手六朗・大高文是，日蓄会影，49：431-436. 1978.

6) 日本豚産肉能力検定研究会，豚産肉能力検定 成 績 年報，第 1 巻：2-5，1959.

7) 茨城県養豚指導所, 豚産肉能力検定成績報告書（昭 和 39，40 および 41 年)：1-55. 1967.

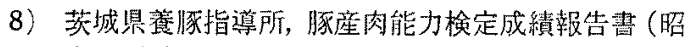
和 42 年)，1-43. 1969.

9）長讯佳熊，分化，5：532-536. 1956.

10）久保彰治, 分化, 11: 864-871. 1962.

11）玉手六朗・大高文男，農化，39：36-39． 1965.

12）齐藤道雄 - 小島正秋，日畜会報，8: 245-262. 1935 .

13) Winton, A. L. and K. B. Winton, The Structure and Composition of Foods (Vol. III), 370-374. John Willey and Sons, Inc., N. Y. 1937.

14) Leverton, R.M. and G. V. Odell, Oklahoma Agr. Exp. Sta. Misc. Pub. 49. 1958.

15) McCance, R. A. and E. M. Widdowson, Chemical Composition of Foods (Edition III), 鈴木理喜子 訳，食品の䑯嘰質会量表：32-33，第 1 出版. 菒京. 1966.

16) Price, J.F. and B.S.Schweigert, The Science of Meat and Meat Products: 165-177. W. H. Freeman and Company. San Francisco. 1960.

17）飯田 稔・中瀬花子，栄意と食糧，15：365-368. 1962. 
18）科学技術厅資源調查会猯，日本食品標準成分表 (三 訂)：56-62，大蔵省印师局. 東京. 1964.

19) InklaAr, P. and J. Sandifort, J. Food Sci., 32: 622-624. 1967.

20）和島昭一郎・滰沢喜造, 坠研, 26：807-812, 937942. 1972.

21）玉手六朗・大高文野，日本焦肉研究会第１2回シン
ボジウム要㫐集，3-5. 1971.

22) 松崎 格, 肉の科学, 11:73-91. 1970 ,

23）日本心ム・ソーセージ工業協同組合，加工用適正

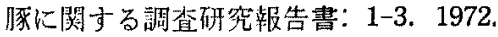

24) Bennink, M.R., G. M. Ward, J. E. Johnson and D. A. Cramer, J. Animal Sci., 27: 600-603, 1968.

\title{
Calcium Content in Pork and the Differences due to Year, Season, Breed, Muscle and Sex
}

\author{
Rokuro Tamate and Fumio Ohtaka \\ Faculty of Agriculture, Ibaraki University, \\ Ami-machi, Ibaraki-ken, Ami-Machi 300-03
}

Representative value for calcium content in pork from 65 pigs of accurately known history was determined by polarographic determination and the differences due to various factors (year, season, breed, muscle and sex) were analyzed statistically. The data on calcium content in pork were classified into five groups by the factors and summarized in Table 1 . The means (95\% confidence limit) of 219 samples were as follows: $6.0 \pm 0.3 \mathrm{mg} \%$ (wet basis), $5.5 \pm 0.2 \mathrm{mg} / \mathrm{g} \mathrm{g}$ of ash. The highly significant differences were found in calcium content of pork among muscles, and the significant differences between seasons and between breeds. However, the differences among years and between sexes were not significant.

Jap. J. Zootech. Sci., 50 (4): 229-234, 1979 